\title{
ULUSAL BAYRAMLARIN TOPLUMSAL IŞLEVLERI AÇISINDAN 30 AĞUSTOS ZAFER BAYRAMI
}

\author{
Prof. Dr. Özer OZANKAYA
}

\section{GIRIȘ}

Genel olarak bayramlar, bir toplumun ortak üstün değerlerinin ve davranış ölçülerinin bireylerce bilinçli olarak, gerekçeleriyle birlikte kavranıp benimșenmesi, yeni kuşaklara da aktarılması bakımından temel bir işlev yerine getirirler. Bu nitelikleriyle bayramlar toplum yaşamının temel alanlarının kurumlaşmasının ve sağlamlaşmasının ana yolları arasında yer alırlar. Bu aynı zamanda toplumsal bütünleşme ve dayanışma ortamının oluşup pekişmesi demektir.

Ulusal bayramlar bu açıdan özel bir önem taşırlar.

Bilindiği gibi ulusal toplum, yakın çağlarda ticaret ve sanayi devrimiyle birlikte ortaya çıkan büyük çaplı, ileri işbölümüne dayalı, organik dayanışmalı toplumdur ve tüm özellikleriyle cemaattan ayrılır. Nitekim bu devrimlerle birlikte söz konusu toplumsal oluşumları inceleyen toplum bilimlerinin de ilk olarak ortaya çıkıp geliştiği Batı Avrupa dillerinde toplum ve topluluk (cemaat) olgularını birbirinden ayırdetmek gereği önemle görülmüş, böylece birine societe, öbürüne ise communeaute denmiştir. Toplum, yani societe biçimindeki ortak yaşamın ayırdedici özelliği, yukarda değinilen karmaşıklı̆ının, büyük boyutunun ve bütünlenmişliğinin bir gereği olmak üzere, temel toplumsal işlevlerin burada kurumlaşmasıdır. Gerçekten ulusal toplum, geleneksel köy, komşuluk, aile ve akrabalık topluluklarında görülenle hiç karşılaştırılamayacak ölçüde yüksek etkinlik gerektiren bir biçimde şu temel işlevlerin yerine getirilmesiyle olanaklıdır:

- güvenlik, adalet ve bağımsızlığın sağlanması ve korünmuş bulundurulması işlevi: bu işlev devlet denilen siyasal kurum tarafından yerine getirilir. 
- bireylerin toplumun temel ölçü ve değerlerine kazanılması işlevi: bunun için aile ve eğitim kurumları'nın örgütlendiğini görüyoruz.

- toplumda gerek duyulan türlü mal ve hizmetlerin, o toplumun kendi gönencini sağlayacak ölçü ve biçimde üretilip yurt yüzeyine ulaştırılması işlevi: bunun için de ekonomi kurumu örgütlenmiştir.

- tüm ulus üyelerinin yaşamı yaşanmaya değer bulmasını sağlayacak yolların araştırıldığı örgütlü kamuoyu.

$\mathrm{Bu}$ temel toplumsal işlevlerin etkin, verimli ve güvenli bir biçimde yerine getirilmesi toplum denilen ortak yaşam biçimi bakımından bir var olma/yok olma sorunu önemindedir. Denilebilir ki bu temel toplumsal işlevlerin bu biçimde karşılanamadığı topluluklar bilimsel olarak toplum sayılmazlar, çünkü orada yapılașmıș, dizgesel bir toplum yaşamı oluşmamış demektir. Nitekim ulusal toplum düzeyine ulaşamamıs olan topluluklar toplum bilimlerinde etnografya malzemesi olarak görülmektedirler.

Kurumlaşma ulusal toplum yaşamı için vazgeçilmez olduğuna göre, kurum kavramının bir tanımını vermek gerekli olmaktadır. Bir toplumsal kurum, üstlendiği işlevin nasll yerine getirilmesi gerektiğini anlatan, birbiriyle eşgüdülüp uyarlanmış düşünceler, duygular, ölçü ve değerlerden kuruludur.

Peki bu düşünce ve duygular, bu ölçü ve değerler hangi yollarla kurumlaşmaktadırlar?

Kurumlaşmanın başlıca süreçleri şunlardır:

1- Söz konusu düşünce ve değerlerin, resmilik kazanması, yani yasalar, tüzükler, yönetmelik ve genelgeler, ile yazılı olarak saptanması, bayraklarla, renklerle, kutlama günleriyle.. simgelenmesi ve böylece herkes tarafından aynı biçimde ve kolayca öğrenilmesinin ve uyulmasının sağlanması.

2- Varlıklarına yönelik tehlikelerin önlenmesi.

3- Bireylerde birer araç olarak değil, kendi başlarına yaşama anlam kazandıran birer amaç olarak benimsenmesinin sağlanmasi.

Ulusal bayramlar, bu kurumlaşma süreçlerinin her birinin gerçekleşmesi bakımından işlevsel bir değer taşırlar. Her yıl belirli günlerde bu temel değerleri vurgulamak üzere iletişim araçlarının yayınlar yapması, okulların kutlama șenlik ve törenleri düzenlemeleri, yerel yö- 
netimlerin, gönüllü derneklerin, meslek kuruluşlarının... bu ortak değerleri kendi çevrelerinde coşkuyla kutlayarak tüm toplumla bütünleşmeleri, türlü alanlarda önderlik ve ya da yöneticilik konumunda bulunanların yayınladıkları demeçler, yürüyüşler, şarkılar, danslar, sergiler... bunlarun hepsi temel toplumsal işlevlerin nasıl yerine getirilmesi gerektiğine ilişkin 'değer ve ölçülerin kurumlaşmasını ve yürümesini kolaylaştırır.

\section{DEMOKRATIK TOPLUMSAL DAYANIŞMA HIZMETINDE ULUSAL BAYRAMLAR}

Ulusal toplum, ulus eğemenliği başta olmak üzere demokrasi ilkeleriyle yönetilen toplum demektir. $\mathrm{Bu}$ bakımdan bayram kutlamalarının bu ilkeler yerine değişmezlik savındaki tek yanlı görüşlerle beyin yıkama çabalarına dönüșmemesi büyük önem taşır. $\mathrm{Bu}$ tehlikeyi önleyecek ana güvence, ulusal bağımsızlık ve ulusal egemenlik ilkelerini devlet, eğitim, aile, ekonomi, örgütlü kamuoyu kurumlarının hepsinin ortak temeli yapmaktır.

Nitekim Türkiye'de de ulusal bayramlar, çağdaş toplum temellerinin kurulmaya başladığı Cumhuriyet döneminde kurulmuş olan bayramlardır. Bunların bir.bölümü aynı zamanda resmi tatil günü yapılarak tüm toplum çapında ve en büyük etkinlikle kutlanmak istenmiştir. Ancak resmi tatil yapılmaksızın da yine tüm toplumun dikkati çekilerek anlam ve önemi vurgulanan ulusal yıldönümü günleri de vardır. Gerek 23 Nisan Ulusal Egemenlik ve Çocuk Bayramı, 19 Mayıs Gençlik ve Spor Bayramı, 30 Ağustos Zafer Bayramı ve 29 Ekim Cumhuriyet Bayramı gibi birinci tür ulusal bayramlarımızın, gerekse Halifelik ve saltanatın kaldırılması, kadın haklarının Kabulü, Yazı ve Dil Devrimlerinin Başlatılması. Türk Yurttaşlık Yasasının Kabulü, Kabotaj Hakkımızın Elde edilmesi,.. gibi ulusal günlerimizin ortak özlerini şu iki ilke oluşturmaktadır:

1- Yurt bütünlüğü ve ulusal bağımsızlık.

2- Ulusal eğemenlik ve insan haklarına dayalı demokratik yönetim biçimi.

Yurt bütünlüğü bakımından ulusal bayramlarımızın tümü Ulusal And (Misak-1 Milli) ile sınırları belirli Türk yurdunun, her türlü tarihsel hukukla sahip olduğumuz ve hiç bir biçimde bölünme kabul etmez öz yurdumuz olduğunu vurgular. Bu yurdun yeraltı ve yerüstü 
zenginlikleriyle, pazarıyla Türk ulusunun gönenci ve onuru için değerlendirileceği, Türk ulusunun tam bağımsız olarak, yani her türlü dış karışmadan bağımsız olarak kendi yurdunun efendisi gibi yaşayacağı ulusal bayramlarımızın ve anma günlerimizin hepsinin canlı tutup pekiştirmeyi ve yeni kuşaklara kazandırmayı amaçladığı temel değerlerdir.

İkinci üstün değerler kümesi olan ulusal egemenlik de, tüm yurttaşların insan haklarına sahip olarak ve özgürce yaşamalarının temeli, vazgeçilmez koşuludur. Kişi ve zümre yönetiminin meşruluk dışı olduğunu, ulusun kendi yönetimini kendi eline aldığını anlatır. Cinsiyeti, dili, dini, mezhebi, mesleği ne olursa olsun, Türkiye Cumhuriyeti'ni kuran tüm bireylerin, yurttaşlık eşit statüsüyle Türk ulusunu oluşturduğunu vurgular.

\section{BIR ÖRNEK: MUSTAFA KEMAL'İN 30 AĞUSTOS ZAFER BAYRAMINI KUTLAYIŞI}

Ulusal bayramların yukarda açıklanan kurumlaştırıcı ve ulusal -toplumsal dayanışma sağlayıcı işleviyle kavranmasının ve buna uygun olarak kutlanmasının en güzel bir örneğini, bu bayramların tümüne imzasını atmış olan Mustafa Kemal'in kendisi vermiştir. 30 Ağustos Zafer Bayramının birinci yıldönümünde, yani daha savaş toplarının sesleri kulaklardan silinmemiş, savaş görüntülerinin imgeleri gözlerden çekilmemişken, bu meydan savaşının yengin komutanı, aynı yerde, tam bir bilimsel bakışla, bu günün ulusal yaşamda hangi üstün değerlerin gerçekleşip kurumlaşması için ortam hazırladığını özenle vurgulamıştır. Bu üstün değerlerin ulusal bağımsızlık, yurt bütünlüğü ve ulusal eğemenlik ilkeleri temeline dayalı olduğu görülmektedir. Mustafa Kemal bu ilkeleri ayrica, bayram günlerinin kendilerinden beklenen işlevi yerine getirmesi için sergilemeleri gereken seçkin bir anlatım güzelliği içinde, bir yandan ulusal coşku ve dayanışma, öte yandan buram buram insanlık sevgisi duyguları eşliğinde getirmiştir.

Mustafa Kemal'in bu yıldönümünde üzerinde durduğu başlıca düşünceler şunlardır:

- Türk yurdunu ele geçirip Türk'ü tutsak etmek düşü ardında koşanlara hak ettikleri ceza verilmiştir.

- 30 Ağustos yalnız bizim değil, tüm insanlığın tarihine yeni bir yön verecek sonuçlar doğurmuştur. 
. - Cumhuriyet yönetimi 30 Ağustos günü sağlam temeller kazanmıştır.

- Ulusun bağılsız ve koşulsuz egemenliği önündeki engelleri, örneğin saltanat ve halifeliği kaldırmanın, kadın haklarını gerçekleștirmenin, eğitim birliği ilkesi ile laik, demokratik bir toplumun yurttaşlarını yetiştirmenin yolları bu zaferle açılmışır diyordu.

Yazımı, Mustafa Kemal'in her bakımdan çok öğretici olan bu yıldönümü konuşmasından kimi seçmelerle bitirmek istiyorum ${ }^{1}$.

“Efendiler, Türk yurdunu ele geçirmek düşüncesini, Türk'ü tutsak etmek düşünü, genel, yaygın bir düşünceye dönüştürmeye çalışanların... lâyık oldukları sondan kurtulamamış olduklarını gözlerimizle gördük. Efendiler, kendilerine bir ulusun geleceği (talihi) güvenilip bırakılan adamlar, ulusun güç ve yeteneğini yalnız ve ancak yine ulusun gerçek ve elde-edilebilir yararları yolunda kullanmakla yükümlü olduklarını bir an düşüncelerinden çıkarmamalıdırlar."

"Türk ulusunun burada elde ettiği yengi kadar kesin sonuç veren ve ... yalnız bizim tarihimize değil, tüm dünya tarihine yeni bir akış vermekte kesin etkide bulunan bir meydan savaşı anımsamıyorum".

"Hiç kuşku duyulmamalıdır ki, yeni Türk devletinin, ' genç Türk Cumhuriyeti'nin temeli burada güçlendirildi. Sonsuzluğu değin sürecek olan yaşamı burada taçlandı..."

"Efendiler, bu pek büyük yenginin türlü etkenlerinin üstünde en önemlisi ve yücesi, Türk ulusunun bağılsız ve koşulsuz olarak egemenliğini eline almış olmasıdır. Bu olayın tarihimizde ve bütün cihanda ne büyük, ne verimle bir devrim olduğunu açılamağa gerek görmem. Ulusumuzun uzun yüzyıllardanberi hanlar, hakanlar, sultanlar, halifeler elinde, onların baskı ve ezinci altında ne denli ezildiğini, onların açgözlülüklerini doyurma yolunda ne denli büyük yıkımlara ve yitiklere uğradığını düşünürsek, ulusumuzun egemenliğini eline almış olması olayının tüm ululuk ve önemi gözlerimizin önünde belirir..."

"Efendiler, ulusal egemenlik öyle bir ışıktır ki, onun karşısında zincirler erir, tac ve tahtlar yanar, yok olur. Ulusların tutsaklığı üzerine kurulmuş kurumlar her yerde yıkılmağa yazgılıdırlar..."

1 Atatürk ün Söylev ve Deme:leri, Türk Inkılap Tarihi Enstitüsü Yay. 19599, s. 173-182. 
“Saraylarının içinde Türk’ten başka ögelere dayanarak, düşmanlarla birleşerek Anadolu'nun, Türklüğün aleyhine yürüyen çürümüş gölge adamlarının Türk yurdundan kovulması, düşmanların denize dökülmesinden daha kurtarıcı bir devinimdir. Türk ulusunun (yurdunda) tam anlamıla efendi olarak yașaması, ancak o gereksiz ve anlamsız olduktan başka, varlıkları yalnızca zarar ve yıkım getiren o makamların ortadan kaldırılmasiyla olanaklı olabilirdi."

“...Efendiler, artık yurt bayındırlık istiyor, zenginlik ve gönenç istiyor. Bilim ve beceri, yüksek uygarlık, özgür düşünce ve özgür düşünüş istiyor."

"Efendiler, ułusumuzun ereği, ulusumuzun ülküsü, bütün cihanda tam anlamiyla uygar bir toplumsal kural olmaktır. Bilirsiniz ki dünyada her ulusun varlığı, değeri, özgürlük ve bağımsızlık hakkı, sahip olduğu ve yapacağı uygar yapitlarla orantılıdır. Uygar yapıt ortaya koyma yeteneğinden yoksun olan topluluklar, özgürlük ve bağımsızlıklarından yoksun kılınmağa yazgılıdırlar... Uygarlık yolunda yürümek ve başarılı olmak yaşamanın koşuludur...

"Efendiler, uygarlık yolunda başarı yenileşmeğe bağıdır. Toplumsal yaşamda, ekonomik yaşamda, bilim ve uygulayım alanında başarilı olmak için tam gelişme ve ilerleme yolu budur. Yaşam ve geçime egemen olan kuralların zamanla değişmesi, gelişmesi ve yenilenmesi zorunludur... Uygarlığın temeli, ilerlemenin ve güçlü olmanın dayanağı, aile yaşamındadır... Aile oluşturan kadın ve erkeğin doğal haklarına sahip olmaları, aile görevlerini yürütmeğe yeterli bulunmaları zorunludur.

"Efendiler, ulusumuz burada saptadığımız yengiden daha önemli bir görevin arkasındadır. O yenginin sonuçlarının tam olarak kazanılması ulusumuzun ekonomi alanındaki başarılarıyla olanaklı olacaktır... Hiç bir uygar devlet yoktur ki, ordu ve donanmasından önce ekonomisini düşünmüş olmasın".

“... Çağın savaşımlarında ulusumuzu başarılı kılacak bir ekonomik yaşam sağlanmasını amaçlayan genel eğitim ve öğretim düzenlerimiz, her gün daha çok temellenecek ve kuşkusuz başarılı olacaktır".

"Efendiler, artık bugün yaşam ve insanlıkgerekleri bütün gerçeğiyle belirmiştir. Bunlara aykırı söylentiler ahlâk ve inanca temel olmaz... Uydurmalar, boş inançlar kafalardan çıkmalıdır. Her 
türlü yükselme ve yetkinle meğe yetenekli olan ulusumuzun toplumsal ve düşünsel devrim atılımlarını kısaltmak isteyen engeller kesinlikle ortadan kaldırılmalıdır".

"Efendiler, son sözlerimi, yalnızca ülkemizin gençliğine yöneltmek istiyorum.

Gençler! Yürekliliğimizi arttıran ve sürdüren sizsiniz. Siz, almakta olduğunuz eğitim ve kültür ile insanlık niteliğinin, yurt sevgisinin, düșünce özgürlüğünün en değerli simgesi olacaksınız.

Ey yükselen yeni kuşak! Gelecek sizindir. Cumhuriyeti biz kurduk. onu yüceltecek ve yaşatacak sizsiniz".

Mustafa Kemal, ulusal bayramların toplumsal dayanısma sağlayıcı asıl özünü böylece vurguladıktan sonradır ki, "Arkadaşlar! Bu savas ve șehitlik beldesinden ayrılırken, 'Șehit Asker'i hep birlikte saygıyla, ağırlayarak selâmlayalım." Çağrısının gerçekten insanları hem olgunlaştırıcı, hem de aralarında dayanıșma kurmalarını kolaylaștırıcı işlevini yapabileceğini de görüyor ve gösteriyordu. 